\title{
Using of Business-Simulation for Forming Entrepreneurial Competences in High Education of Ukraine
}

\author{
V. Pazdrii1**, P. Banshchykov², O. Gryschenko' ${ }^{1 .}$ \\ ${ }^{1}$ Company of Intellectual Technology (KINT), ${ }^{2}$ Kyiv National Economic University \\ *Corresponding author. E-mail: pazdriy.v@gmail.com, bpg@kneu.edu.ua \\ Paper received 20.09.17; Revised 27.09.17; Accepted for publication 30.09.17.
}

https://doi.org/10.31174/SEND-HS2017-146V24-02

\begin{abstract}
In this article we describe the first and most popular Ukrainian business simulation ViAL+. It is an interactive system, modelling main business processes at the real market. The interactive learning environment focuses on the competition between "real" participants in a virtual economy and opportunities for forming economic and managerial competences. We describe main parts of design Businesssimulation ViAL+, main branches of using and our result for last 5 years.
\end{abstract}

Keywords: component; business-simulation, Ukraine, youth, entreprenership education.

Introduction. Finding a solution for the problems of practical training in the context of basic education, and deepening the knowledge and skills of professionals is becoming more and more urgent in post-industrial information economies. Creating a business simulation close to real economic processes, including market processes, we distinguished two approaches of practical management skills training: on the job training - learning in real work conditions, and learning through business games. In the first option, real risks and the price of making errors may be very high. The second approach offers a safe learning environment for experimenting with various solutions to management problems.

Current advances in information technology enable the development of business simulations close to real situations. Under the auspices of "Vadym Hetman Kyiv National Economic University" and the industrial research-and development centre of The National Academy of Sciences of Ukraine, a group of young scientists and practitioners developed the business simulation ViAL+, which is a large-scale interactive simulation system. ViAL+ creates a realistic virtual business economy and a lively competition between the participants, while pursuing practical solutions to realistic business problems.

The main goal of the ViAL+ is to create opportunities for acquiring practical skills in dealing with integrated business process management, taking into account the whole chain of production, distribution and sales in a market economy.

The online use of ViAL + aims at training bachelors and magister in economics. Also business-simulations is main for providing entrepreneurship education at the school/ In addition, we use ViAL+ for organizing business-championship for pupils and students (in Ukraine and world), and for training young entrepreneurs, for unemployed persons.

General description and desighn of ViAL+. Business simulation $\mathrm{ViAL}+$ is a large-scale simulation system that modelling working of production company and competition market. There is created training environment, in which participants can make management decisions in the business simulation $\mathrm{ViAL}+$. The business environment created by the participants. There is the best approximates market simulation software to real business environment. Until the next period of participation in the simulation, each player management decisions can be corrected - it gives the opportunity to try all the options, use and evaluate various business strategies.

There was created departments and business-processes of production, marketing, finance, personal, analytics, accounting in ViAL+. Only real person (participant) make decisions of management of company. We have external resources: finance, equipment, raw material, shops 'For trade of prod- ucts); own products for modelling consumers and main components other real competitors. Competition is organize only between real participants 'Fig. 1). The business environment created by the participants that best approximates market simulation software to real business environment. Computer is only help to organize comfort process and education. Until the next period of participation in the simulation, each player management decisions can be corrected - it gives the opportunity to try all the options, use and evaluate various business strategies.

Cycle of firm in ViAL + consists of rounds, one for each quarter real activity. Taking decisions regarding production, its advertising and marketing, recruitment and improvement of assets, personnel, etc. The owner of a virtual company determines the direction and performance of the company in each period. Management company in the business simulation through the organization of several of its business units, such as Production Department, Marketing and Sales, Department Personnel, Finance Department, Accounting, Department of operational control.

Like a real business, successful business in ViAL + provides competition for superiority, or at least profitable market share. In the simulation, you can use tools such marketing exposure:

1. Pricing.

2. An advertising campaign.

3. Formation of range and assortment of products occurs is the results of the decision:

a. identification number nomenclature groups;

b. planning product mix in each nomenclature groups by using various additives and fillers and various types of packaging.

4. Development of own sales network involves the construction of their retail space. Impact on the market is the number and capacity of its own stores, as thus defined territorial presence of the company and the level of contact with their customers.

5. Creating a positive image of the company - the tool is formed for a long time (several periods) of staying in the market and fully depends on the assessment by consumers of the company. The main components forming the image of the business simulation $\langle\mathrm{ViAl}+\rangle$ are:

a. the presence of the company in this market segment, which is manifested in particle size segment, which the company acquired in previous periods;

b. the ability to meet demand - consumers business simulation «ViAl +» quite responsive to the absence or insufficiency of supply to the market with active marketing policy, which is manifested in the loss of consumer confidence in these periods.

Maximum functionality and information in business- 
simulation make effective decisions of particiapnts. Matching actual conditions of the domestic economy and the laws of the market, the effect of "live" business environment that the participants are doing, ensure efficiency and effectiveness ViAL + as a business simulator for teaching entrepreneurship.

During the period of participation in business simulation ViAL+ participants goes through several stages 'Fig. 1):

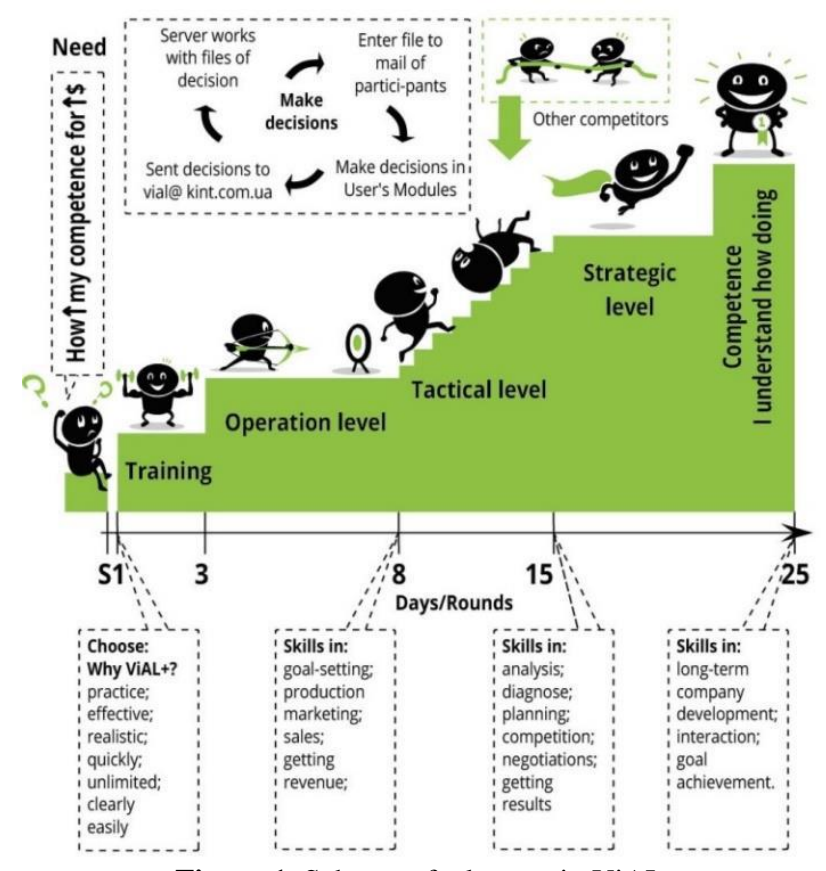

Figure 1. Scheme of take part in ViAL+

1. educational stage during first three periods;

2. adaptation to the simulation environment during 4-7 sessions takes place;

3. formulate by participation an integrated vision of the company as a system, which, simultaneously, consists of interrelated functional units during 8-10 sessions;

4. an understanding of the causeand-effect relations in economic management of the company in a competitive market environment (15-18 sessions);

5. after the 20th session the participant can consciously implement and correct the earlier formed plan of action, he begins to professionally analyze the results;

6 . the reinforcement of acquired competences and practical skills is observed after 25 sessions.

Cycles of decisions have main 4 phases 'Fig. 7): planning $\rightarrow$ production $\rightarrow$ pricing $\rightarrow$ selling. There are other optional steps such as buying/selling, modernization equipment, advertising, development of new products, deposit/credit operations, financing, management of personal, analytics.

In order to develop a profitable business, you need a good understanding of the features of the market, which will have to promote their products or services.

Analyzing these data when ordering research services displayed on the tab "market information" participant can create an elaborate strategy to promote their companies in the segment of products.

Once the products are produced, there is a logical question: where to sell it? Among ViAL + simulation are three ways for trade of products. Delivery of products can be carried out fully or partially in any sales network:

1. Own sales network. Participant build shops, which sells its own product and, if you wish, earning a lease providing this service to competitors. The area and number of outlets identifies the owner himself.

2. Retail service by other companies are available in unlimited quantities diving.

3. Shops competitors. If the construction of its own outlets for some reason impractical may rent space for trade in other members of simulation.

Evaluation of participants in ViAL+. According to the results of virtual firms formed their $\mathrm{ViAL}+$ rating. It includes several important criteria: overall score, profit, market share, productivity, profitability, net cash flow ratio and current ratio of the total number and amount of contracts, total assets, product range, efficient use of raw materials and retail space.

This approach allows us not only to identify the company leader, but each participant to reveal its strengths and weaknesses and put tasks for future work on themselves.

The strategic goal of business simulation $\mathrm{ViAL}+$ is to create a dynamic and successful company in the market of dairy products. Comprehensive assessment of each member regarding its decision-making and its partners / competitors formed through the rating system, the overall scoring, which is based on the evaluation of 13 indicators 'Fig. 10).

Rating is calculated in three stages:

1. A ranking between companies for each measure separately. The best indicator gets maximum score (equal to the value of the number of companies), and 0 points receives a company party or the lowest index with a value beyond the permissible.

2. Rank score is multiplied by a weight indicator for each company. Weight indicator formed input of particular training, practice or tournament in business simulation ViAL + . But the importance / negligibility member of each indicator is determined independently based on its own analytical thinking, attitudes, purposes.

3. At the end of counting occurs summation of products ranking points from their weights and formation of final assessment in points.

All figures are marked rating 4 content groups:

1) performance status of the company;

2) performance of financial condition;

3) performance marketing and external action;

4) indicators of internal environment.

Using of business-simulation ViAL+. Businesssimulation ViAL+ was created for education in post-soviet countries. There are many stereotypes for people (such as entrepreneur are criminal), very hard conditions for open and development of business, orientation only by profit, must be very high profitability of company (more 20-30\%) and other special features at the post-soviet environment. But at the other side we must formulate and provide European, free market, liberal principals of making business. This task are resolving by ViAL+.

Project of Business-simulation ViAL+ started on 2007. But only at the autumn of 2012 have been first sallied for university. During 2012-2017 on the basis of business simulation ViAL+ following activities are held:

1. All-Ukrainian and International business-tournament for youth, teachers and entrepreneurs "Strategy firm" (organised by Kyiv National Economic University, Company of Intellectual Technology, Ministry of Education and Science, KPMG);

2. local business-tournaments/championships for students and pupils; 
3. interactive business practice, trainings and providing to disciplines of high education;

4. licensing for educational organization;

5. based for state project "Development of Business Education in Ukraine" provide by Ministry of Education and Science;

6. training for corporative segment.

Learning efficiency of ViAL+ is providing by such factors:

1. Participation in ViAL+ gives an opportunity to get practical management skills of management of economic processes, in the context of individual functional services of the company, and of the process of companies management in whole.

2. Participant can make all decision in ViAL+ environment, what he/she want. We create entrance conditions market, modelling consumer, source of resources, pricing parameters and etc, -- and also create potential ideal functional production system, which work without human factor (all decision realize, equipment forecast work). But the main purpose of participant - build production and marketing system according to his/her knowledge and skills.

3. Trainer can make different learning situation for students. And participant can show competence in practical conditions in very small time and without risk.
4. ViAL+ is bridge between real situation and theoretical knowledge.

5. ViAL+ form positive emotion and opportunities for future of youth, which are very important at the epoch of crisis.

Conclusions. The main results of article about businesssimulation $\mathrm{ViAL}+$ are:

1. In Ukraine was creating no scenario and complex business-simulation ViAL+, which modeling production company and real competitive environment. The fundament of VAL+ is maximum approaching to real market and situation.

2 . We create autonomy real business environment. Because business-simulation ViAL+ can be base for standardization of level economic and manager competences.

3. Business-simulation ViAL+ is modeling production company with 5 departments: production, market and sale, personal, finance, accounting. Admin module is modeling market and consumer behavior, is accessing adjustment of all parameters of $\mathrm{ViAL}+$, registration new market and participants.

4. ViAL+ is adaptive to experimental learning - training, practice for developing management skills. Also ViAL+ will open opportunity to assess of competence level.

5 . There were more 8.4 thousands of young and older participants in ViAL+ during 5 years. We create new innovative young

\section{REFERENCES}

1. Pazdrii Vitalii, Gryschenko Oleksandr, Banschykov Petr. "Business Simulation Vial+ - An Interactive Learning Environment for Developing Management Skills". Title: THE SHIFT FROM TEACHING TO LEARNING: Individual, Collective and Organizational Learning through Gaming Simulation. Proceedings of the 45th Conference of the International Simulation and Gaming Association, Dornbirn, 2014. Editors: Willy C. Kriz, Tanja Eiselen, Werner Manahl. Publisher: W. Bertelsmann Verlag GmbH \& Co. KG, Bielefeld, Germany ISBN: 978-3-7639-5422-3 pp. 476-488.

2. Pazdrii Vitalii. "Presantation of Business Simulation ViAL+" Title: THE SHIFT FROM TEACHING TO LEARNING: Individual, Collective and Organizational Learning through Gaming Simulation. Proceedings of the 45th Conference of the International Simulation and Gaming Association, Dornbirn, 2014. Editors: Willy C. Kriz, Tanja Eiselen, Werner Manahl. Publisher: W. Bertelsmann Verlag GmbH \& Co. KG, Bielefeld, Germany ISBN: 978-3-7639-5422-3 pp. 872-873.

3. Banschykov P., Skiteva G. Forming of system trainings: experience of strategy firm department of Kyv National Economic University (Банщиков П.Г., Скитьова Г.С. Формування системи тренінгів: досвід кафедри стратегії підприємств / П.Г. Банщиков, Г.С. Скитьова // Тренінгові технології як засіб формування знаннєвих та практичних компетенцій: досвід факультетів і кафедр: зб. матеріалів наук.-метод.

конф. 3-4 лютого 2009 р.: у 2 m. - T.1. - К.: КНЕУ, 2009.c.114-117.)

4. Company of Intellectual Technology, http://kint.com.ua/.

5. GlobalChallenge-description of business simulation, http://www.globalchallenge.ru.

6. Kotler Philip, Armstrong G. Principles of Marketing, $11^{\text {th }}$ edition, 2003 (Котлер Ф., Армстронг Г. Основы маркетинга, 9-е изд.: Пер. с англ.-М.: Издательский дом «Вильямс», 2003.1200 c.).

7. Kundyscheva E. Mathematic modeling in the economy, 2004. (Кундыщева Е.С. Математическое моделирование в экономике: учеб. Пособие.-М.: Даиков и К, 2004.-352 с.)

8. Serdjuk V., Zajukov I. Modern (Сердюк В. Р., Заюков I. В. Сучасні підходи до професійної підготовки економічно активного населення як складової інновачиійного розвитку економіки України: Монографія. - Вінниия: УНІВЕРСУМВінниця, 2007. - 177 c.)

9. Shoptenko V., Kajsina O. Experience of using of businesssimulation at the integrated educational courses, 2008 (Шоптенко В., Кайсина О. Опьт использования бизнессимуляиий в интегрованных образовательных курсах//Менеджер по персоналу.—№3.—2008.—с.32-42.)

10. Stigler J. Theory of Firms, 1995 (Стиглер Дж. Теории фирмы.-СПб.: Экономическая школа, 1995.-245 с.)

\section{Использоване бизнес-симуляций для формирования предпринимательских компетенций в высшем образовании \\ В. Я. Паздрий, П. Г. Банщиков, А. В. Грищенко}

Аннотация. В этой статье мы описываем украинскую бизнес-симуляцию ViAL +. Это интерактивная система, моделирующая основные бизнес-процессы на реальном рынке. Интерактивная учебная среда фокусируется на конкуренции между «настоящими» участниками виртуальной экономики и возможностями формирования экономических и управленческих компетенций. Мы описываем основные части дизайна бизнес-симуляций $\mathrm{ViAL}+$, основные отрасли использования и наш результат за последние 5 лет.

Ключевые слова: бизнес-симуляиия, Украина, молодежь, обучение предпринимательству. 